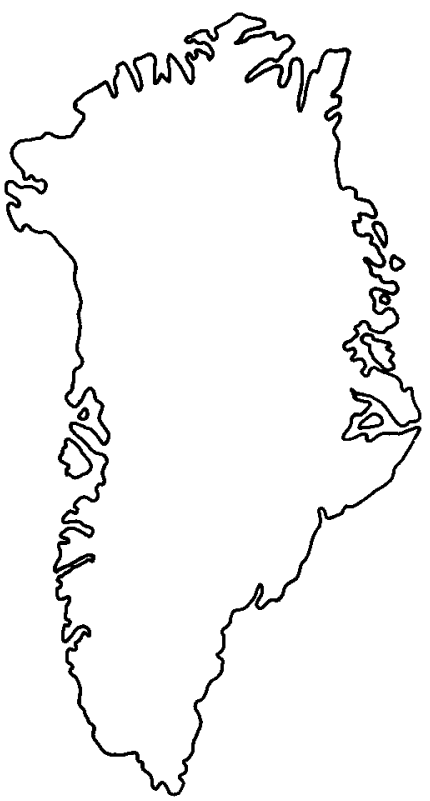

\title{
Cambrian and Silurian sponges from North Greenland
}

\author{
J. Keith Rigby
}

Three genera of sponges are described for the first time from the Lower Palaeozoic of North Greenland. ?Vauxia gracilenta Walcott, 1920 and Choia hindei (Dawson, 1896) are reported from the Buen Formation of Early Cambrian age; the specimens of the latter species are the largest known examples of Choia. A single specimen from the Chester Bjerg Formation of Late Silurian age is described as Diagoniella mica sp. nov., and is the smallest known species of the genus.

J. K. R., Department of Geology, Brigham Young University, Provo, Utah 84602, U.S.A.

The Lower Palaeozoic rocks of North Greenland form part of the Franklinian Basin which extends across North Greenland and the arctic islands of Canada. A general stratigraphic review is given by Peel (1982). Recent fieldwork in North Greenland has yielded three genera of sponges, specimens of the demosponges Choia hindei (Dawson, 1896) and ?Vauxia gracilenta Walcott, 1920 from the late Early Cambrian Buen Formation, and the lyssacinosid hexactinellid Diagoniella mica sp. nov. from the Silurian Peary Land Group. These are the first sponges to be described from the Cambrian and Silurian of Greenland, respectively, although Troedsson (1928) described sponges from the Ordovician of Washington Land, western North Greenland, which he assigned to Aulocopium aurantium Oswald, 1895 and Heterospongia sp., and Poulsen (1937) recorded an indeterminate species from the Lower Ordovician of East Greenland. Isolated spicules of the genus Chancelloria Walcott, 1920 are known from various localities in North Greenland in strata principally of Early and Middle Cambrian age (J. S. Peel, personal communication, 1986) but are not yet illustrated or described. This problematic organism has generally been considered to be a sponge, although Bengtson \& Missarzhevsky (1981) have referred it to a new group termed Coeloscleritophora.

The first sample of Choia hindei from Greenland was found in 1984 by N. J. Soper in the upper shales of the Buen Formation just east of central J. P. Koch Fjord (GGU sample 313035 , locality 1 in fig. 1). In 1985 , the same locality yielded abundant trilobites, bradoriid ostracods and ?Fordilla, a fauna of late Early Cambrian age comparable to largely undescribed faunas known from the formation elsewhere in central North Greenland (J. S. Peel, personal communication, 1986). After preliminary identification by Peel, the specimen was sent to the writer for further study.

In 1985 numerous samples of Choia hindei were recovered from the highest shales of the Buen Formation on the west side of central J. P. Koch Fjord by N. C. Davis and A. K. Higgins (GGU sample 319543, locality 2 in fig. 1). The samples of ?Vauxia gracilenta occur on 


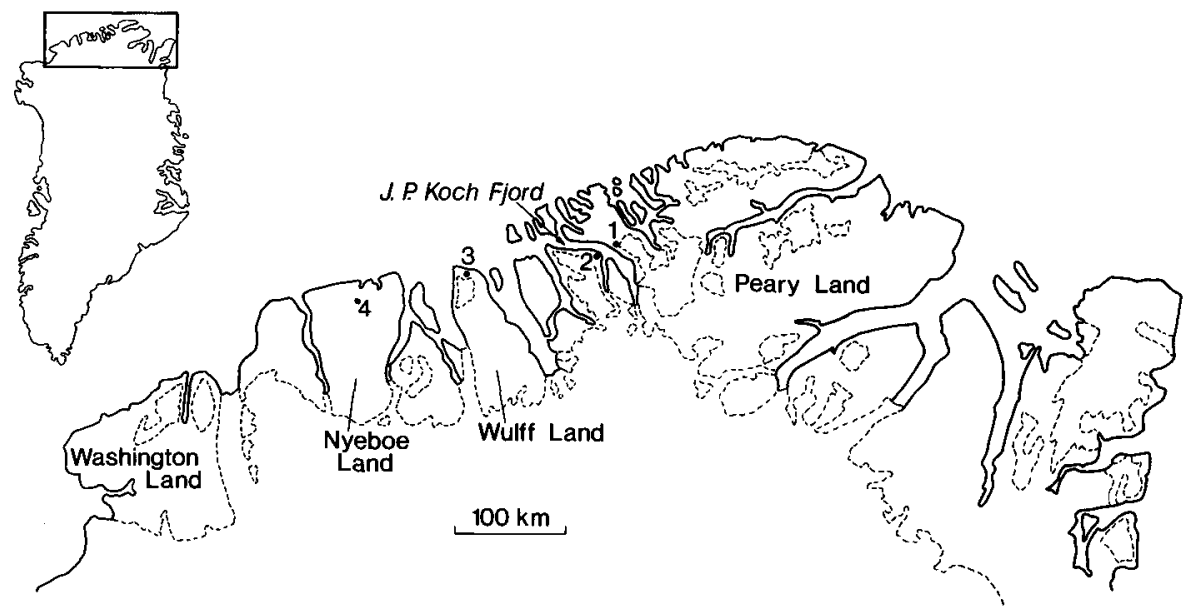

Fig. 1. North Greenland showing the localities from which sponges described in the text were collected. 1, Choia hindei, GGU sample 313035; 2, Choia hindei and ?Vauxia gracilenta, GGU sample 319543; 3 , Choia hindei, GGU sample 319711; 4, Diagoniella mica sp. nov., GGU sample 315484. Localities 1-3 are within the Buen Formation (Early Cambrian); locality 4 lies within the Chester Bjerg Formation (Late Silurian).

the same slabs. This locality has also yielded trilobite remains but these, like the trilobites from locality 1 (fig. 1) await determination.

A further sample of Choia hindei was collected by A. K. Higgins in 1985 from northern Wulff Land, again from a high level in the Buen Formation (GGU sample 319711, locality 3 in fig. 1). The collection also contains bradoriid ostracods and ?Fordilla.

The specimen of Diagoniella mica was recognised by M. Bjerreskov during systematic study of Silurian graptolites collected in 1984 by J. C. Escher and P.-H. Larsen. The collection (GGU sample 315484) was derived from the Chester Bjerg Formation of the Peary Land Group in Nyeboe Land (locality 4 in fig. 1). Graptolites from the same collection indicate an early Ludlow (Late Silurian) age (M. Bjerreskov, personal communication, 1985). A description of the Peary Land turbidite sequence is given by Larsen \& Escher (1985).

\section{Systematic palaeontology}

Class Demospongea Sollas, 1875

Subclass Ceractinomorpha Lévi, 1956

Order Verongida Bergquist, 1978

Family Vauxiidae Walcott, 1920

Genus Vauxia Walcott, 1920

Type species. Vauxia gracilenta Walcott, 1920. 
?Vauxia gracilenta Walcott, 1920

Figs 2B-E, 4A

Description. Four blocks in GGU collection 319543 from locality 2 (fig. 1) show numerous fragments of a branching sponge(?). Individual branches are 2-3 $\mathrm{mm}$ across, for $6-8 \mathrm{~mm}$, before flaring abruptly to 4 or $5 \mathrm{~mm}$ across in the upper part of the branches (fig. 2C), or just below where additional branches may have their origin. No complete specimens are preserved but the most complete is approximately $35 \mathrm{~mm}$ long. It shows three levels of branching, $6-8 \mathrm{~mm}$ apart, but it has a torn base and top. Most other fragments are $2-3 \mathrm{~mm}$ wide, although a few may be up to $3.5-4.0 \mathrm{~mm}$ across.

Most fragments show only the dense, probably dermal, layer in which there is little structure shown. These generally appear as smooth, highly reflectant pyrite or limonite surfaces. On one of the blocks, however, there are numerous areas where details of the skeletal net appear better preserved and the double-layered nature of the skeleton is evident (figs $2 \mathrm{D}$, E). The inner, irregularly preserved layer is made of fused fibrous elements that outline crudely rectangular to rounded hexagonal openings. The inner net appears to have been a thin, sheet-like feature. Individual openings in the net are approximately $0.3-0.4 \mathrm{~mm}$ wide and $0.4-0.5 \mathrm{~mm}$ high, although with considerable irregularity. Where best preserved, there are six or seven vertical series of crudely stacked openings across a flattened branch approximately $3 \mathrm{~mm}$ wide. Individual fibres around the openings are $0.08-0.12 \mathrm{~mm}$ wide, but have irregular margins and are not sharply defined. They are thinnest in the middle of individual segments, along openings, and become thickest near their junction with the rung-like fibres in the ladder-like or wire net-like skeleton. Generally speaking, what is interpreted here as the endosomal net is totally obscured elsewhere by the dermal layer, which appears to be essentially structureless.

Discussion. Among the known Cambrian sponges, only the genus Vauxia Walcott, 1920 has a fused skeleton composed of an open net overlain by a dense dermal layer. In fact, many of the fragments from North Greenland appear strikingly similar to many of those from the Burgess Shale locality from where the several species of Vauxia were first described (Walcott, 1920, pp. 318-322). There, too, the dense dermal layer has obscured the net-like endosomal layer on most specimens.

Of the species of Vauxia described by Walcott (1920), the most similar is $V$. gracilenta (Walcott, 1920, pp. 318-320; Rigby, 1986, pp. 17-19). V. gracilenta is a simple to complexly branching sponge that is the most common sponge in the Burgess Shale assemblage, presumably because it had a leathery texture that was not disrupted during transportation. The overall proportions of branches and element of the skeletal net in the North Greenland sponges are much like that in type specimens of Vauxia gracilenta. These, too, have openings in the endosomal layer, approximately $0.3-0.4 \mathrm{~mm}$ across and high, and have a confused, oftentimes apparently structureless dermal layer. In the Burgess Shale material, however, some specimens show a clear separation of endosomal and dermal layers. This type of preservation was not seen in the material from Greenland.

Vauxia magna Rigby, 1980 as described by Rigby (1980, pp. 234-240) and Vauxia ampliata Rigby, 1985 as described by Rigby (1986, pp. 21-22) have skeletons with endosomal nets sev eral times coarser than that observed in the specimens from Greenland. Vauxia venata Walcott, 1920 as described by Walcott $(1920$, p. 322$)$ is a broadly conical, expanding, branched 
sponge and has a growth form quite different from that seen in the Greenland material. Vauxia bellula and Vauxia densa, as described by Walcott (1920, pp. 320-321), are relatively simple, elongate, tubular, species but their individual branches are relatively large; this character separates them from the ?Vauxia of the Greenland locality.

Material. MGUH 17073, 17074, and 17075 from GGU sample 319543 from the Lower Cambrian Buen Formation of North Greenland. Three other blocks containing fragments of the possible sponge were collected from the same locality. some fragments are also associated with the nearly complete large specimen (MGUH 17070) of Choia hindei, described below. The specimens from Greenland are referred to the genus and species with some reservation because of their relatively poor preservation and fragmental nature.

Order Monaxonida Sollas, 1883

Family Choiidae DeLaubenfels, 1955

Genus Choia Walcott, 1920

Type species. Choia carteri Walcott, 1920.

Choia hindei (Dawson, 1896)

Figs 3, 4A, B

1896. Stephanella hindei Dawson, p. 117, text-fig. 28.

1920. Choia hindei (Dawson); Walcott, pp. 295-296, Pl. 76, figs. 1, 1a.

1977. Lenica unica Gorjansky, pp. 274-276, fig. 1.

1983. Choia hindei (Dawson); Rigby, pp. 253-255, fig. 5 b.

Diagnosis. Large choiaid sponge with central thatched disc composed of oxeas; coarse coronal oxeas up to $1.4 \mathrm{~mm}$ in diameter with most approximately $0.6-0.7 \mathrm{~mm}$ across and up to 11 cm long; thatch spicules considerably finer, possibly of two ranks; longer somewhat coarser oxeas, $0.05-0.16 \mathrm{~mm}$ in diameter and $10 \mathrm{~mm}$ long. Finer, tightly packed, spicules make up most of the thatch and are approximately $0.02-0.03 \mathrm{~mm}$ in diameter and up to $6 \mathrm{~mm}$ long.

Fig. 2. Diagoniella mica sp. nov. and ?Vauxia gracilenta Walcott, 1920 from North Greenland. A, holotype of Diagoniella mica sp. nov. showing the general balloon-like, smooth-walled form of the species, its small size and its skeleton made of up to 4 ranks of diagonally-oriented stauractines. Spicules show best near the base (?), toward the right. MGUH 17076 from GGU sample 315484, Late Silurian, from the Chester Bjerg Formation, North Greenland, $\times 10$. B-E, ?Vauxia gracilenta Walcott, 1920, Early Cambrian Buen Formation, North Greenland. b, fragments of the sponge, apparently buried in a thin turbidite deposit, in black siliceous shale. The internal skeletal net shows well in specimens near the centre and upper centre. Branching shows best in lower centre specimens. Most other have torn margins, $x$ 1. C, moderately well-preserved, branching, fragment showing lower stolon-like parts that increase in diameter abruptly upward. Skeletal detail is obscure in the flattened, largely limonite-replaced fossils in the black siliceous shale MGUH 17073 from GGU sample 319543. D, E, photomicrographs showing the net-like inner skeleton of two fragments, MGUH 17074 and MGUH 17075, shown near the top of the block in figure 2B. The fused net-like skeleton is known in other Cambrian sponges only in the genus Vauxia, $\times 10$. 


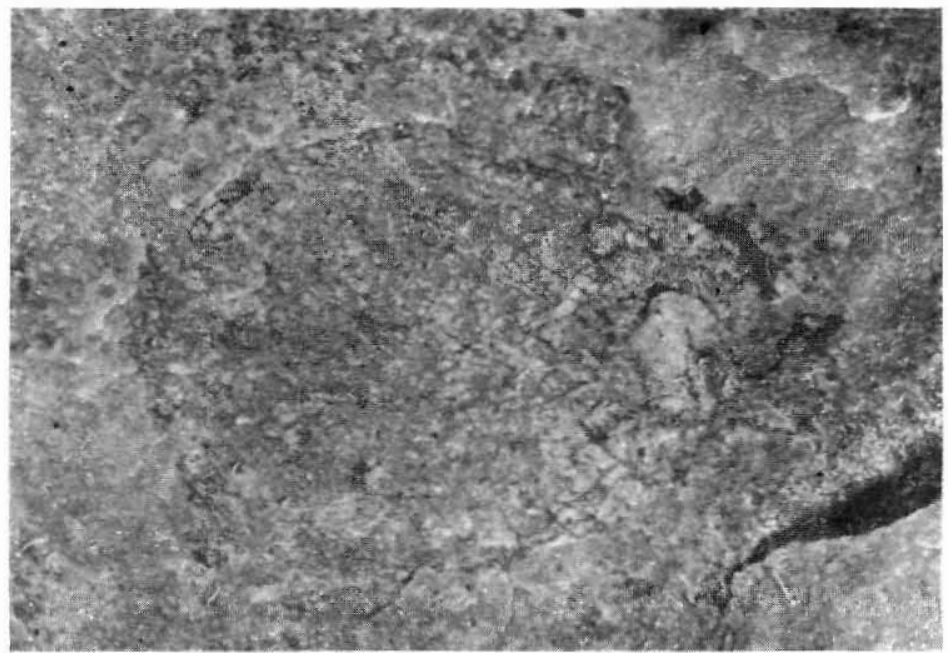

A
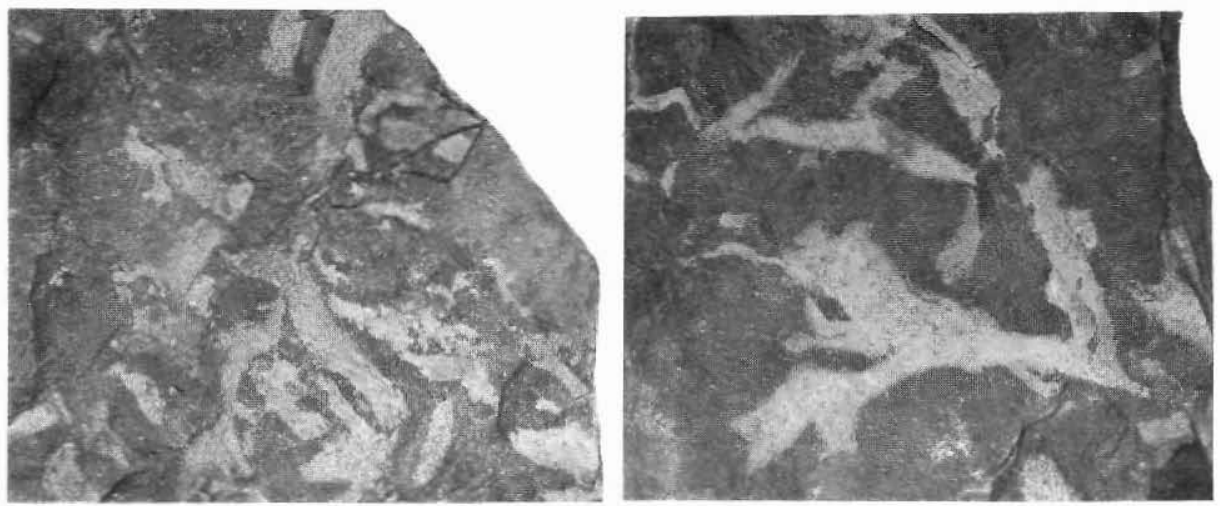

B

C

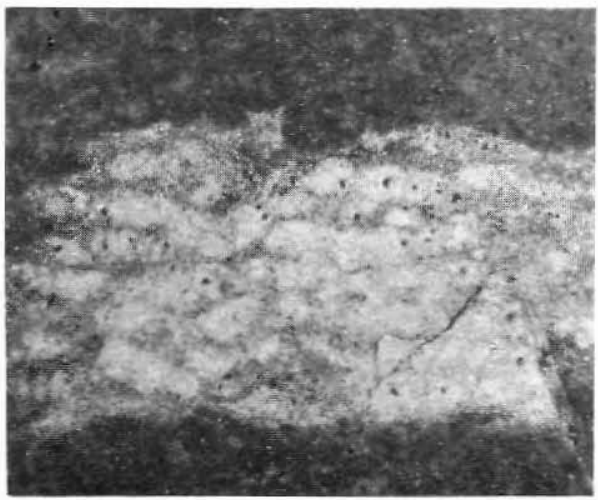

D

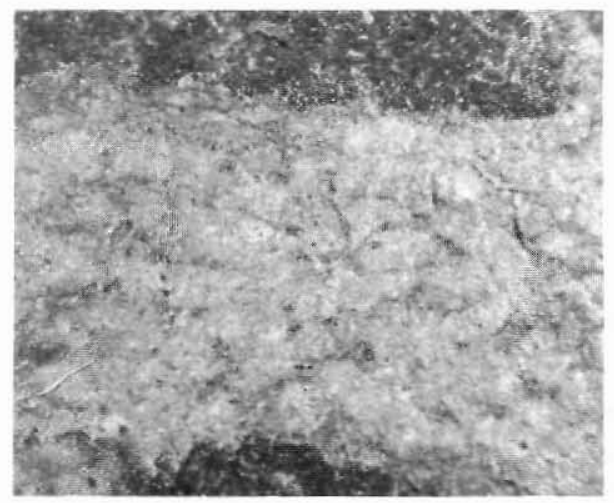

E 
Description. The several specimens in the collection range from nearly complete specimens to only fragments. All are on black siliceous shale and include all or part of the radiating thatch of the central disc and the coronal spicules. The complete edge of the central disc is nowhere preserved. In the first-found specimen (MGUH 17071 from GGU sample 313035) thatch spicules radiate out from a crude centre that covers an area $3.5 \mathrm{~cm}$ in diameter at the disc centre (figs 3, 4B). A few spicules extend a distance of $11 \mathrm{~cm}$ on the preserved fragment to the broken edge, but only $4-7 \mathrm{~mm}$ in opposite directions, on the somewhat rectangular matrix block that is $15 \times 14 \mathrm{~cm}$.

The most nearly complete specimen recovered during the 1985 field season (MGUH 17070 from GGU sample 319543) is approximately three-quarters of a large flattened sponge. A prominent coarse radial corona surrounds the large somewhat less well-preserved, central disc (fig. 4A). The central disc has a radius of $10-11 \mathrm{~cm}$ and is composed of a thatch of fine oxeas that radiate out from a somewhat matrix-covered centre. The large coronal oxeas are up to $17 \mathrm{~cm}$ long and generally extend $10-12 \mathrm{~cm}$ beyond the fairly ill-defined margin of the central disc. If complete, the specimen would be approximately $35 \mathrm{~cm}$ in diameter, based on maximum lengths of large coronal spicules preserved in limonite on half of the sponge where the skeleton is most evident.

A somewhat less complete specimen (MGUH 17072 from GGU sample 319711) is smaller and has a radius of approximately $15 \mathrm{~cm}$ in the two clusters of large coronal oxeas that represent the specimen. These extend out from an incomplete fragment of thatch of the central disc. The disc is preserved so irregularly that little other than a gross radius of approximately $7 \mathrm{~cm}$ can be given.

The central part of the disc, in the lower part of MGUH 17071 (fig. 3), is composed of a finer thatch in which coarse coronal spicules do not occur. Coronal spicules are limited to a lower part of the flattened specimen, anatomically, and are most evident in the upper half of the fragment. As flattened, the specimen appears to have a minimum central disc diameter of approximately $20 \mathrm{~cm}$. The total distance that coronal spicules extend beyond the central disc is unknown because of the manner in which the specimen has been broken.

The coarse coronal oxeas are smooth, doubly tapering, up to $9 \mathrm{~cm}$ long, and have maximum diameters of approximately $0.5-0.6 \mathrm{~mm}$ at mid-length or toward the proximal end of the unequally tapering spicules. Most of the fragments appear to be approximately $6-7 \mathrm{~cm}$ long and occur at various levels in the lower thatch. They are crudely radiating from the centre of the disc and are more or less unequally distributed. At approximately $5 \mathrm{~cm}$ from the centre of the thatch, they occur at 8-9 per $\mathrm{cm}$, measured at right angles to their trend. Distal taper is evident on virtually all coronal fragments. Proximal taper and tips, however, are evident on only a few fragments because they are generally inserted into the thatch of finer oxeas that make up the bulk of the sponge. Coronal spicules are overlain by thatch of the upper part of the sponge, according to the model of the genus given by Rigby (1986, text-fig. 13).

Coarsest coronal oxeas in the nearly complete specimen (MGUH 17070 from GGU sample 319543) are up to $17 \mathrm{~mm}$ long and have maximum diameters, at mid-length, of approximately 1.3-1.4 mm. These spicules clearly show both proximal and distal taper and are smooth and flattened. They are now preserved largely as moulds or locally as limonite pseudomorphs after the spicules. Many show grooves of collapse, as though the coarse oxeas had large axial canals that caved in during diagenesis. In some forms, collapse may have followed partial replacement by pyrite of the outer part of the spicule so that only a rind remained when compaction distorted the normally cylindrical-looking spicules. 


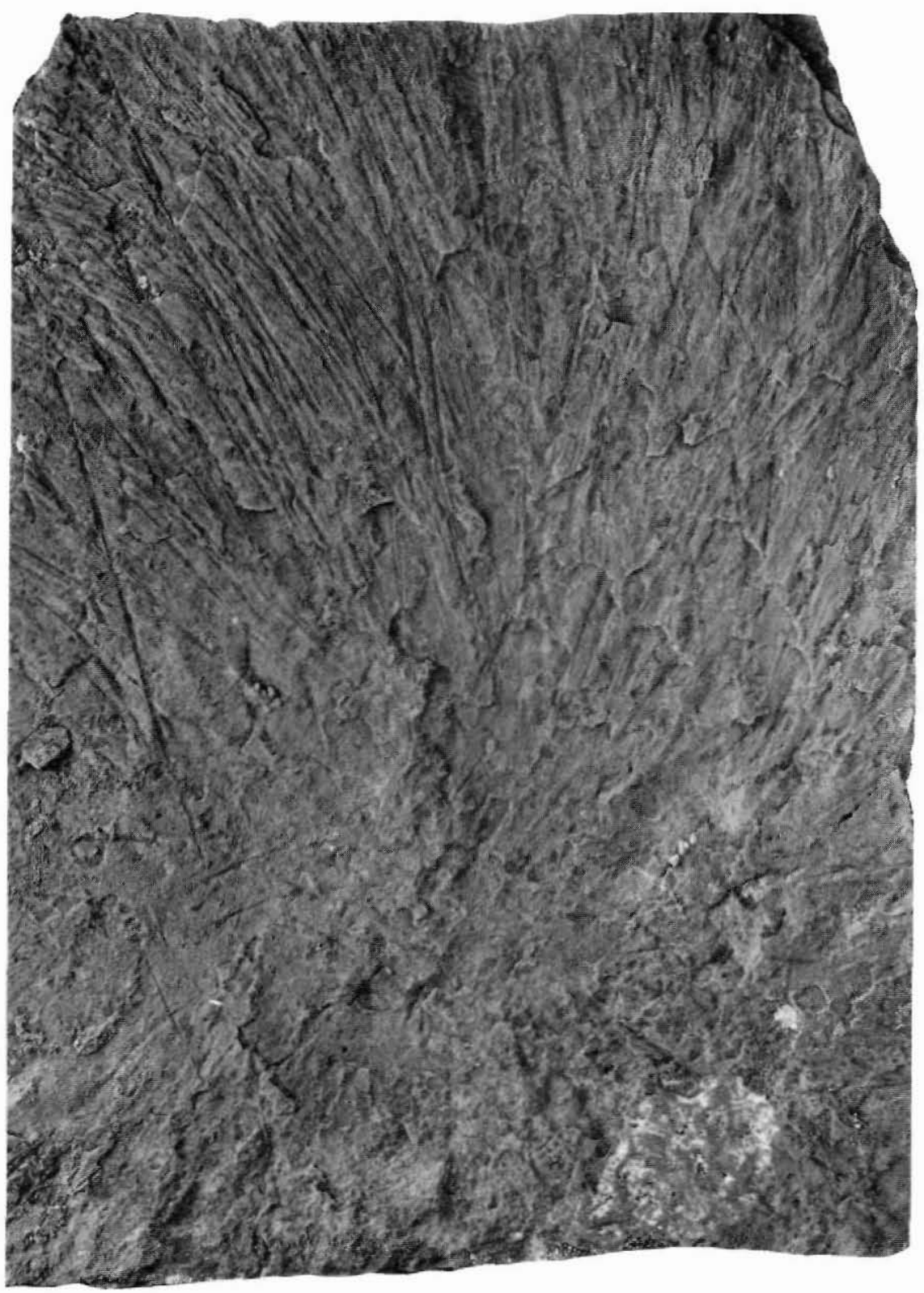

Fig. 3. Choia hindei (Dawson, 1986). A somewhat ill-defined central disc of radiating thatch occurs near the lower centre, and is made up of fine oxeas that have left only weak impressions. Coarse coronal spicules radiate out from the central disc and show particularly well in the upper half of the specimen, as figured. Most spicules are preserved in negative bas-relief where the limonite-replaced spicules have been removed, but moulds show in the black siliceous shale. Early Cambrian, North Greenland, from the Buen Formation, MGUH 17071 from GGU sample 313035, × 1 . 

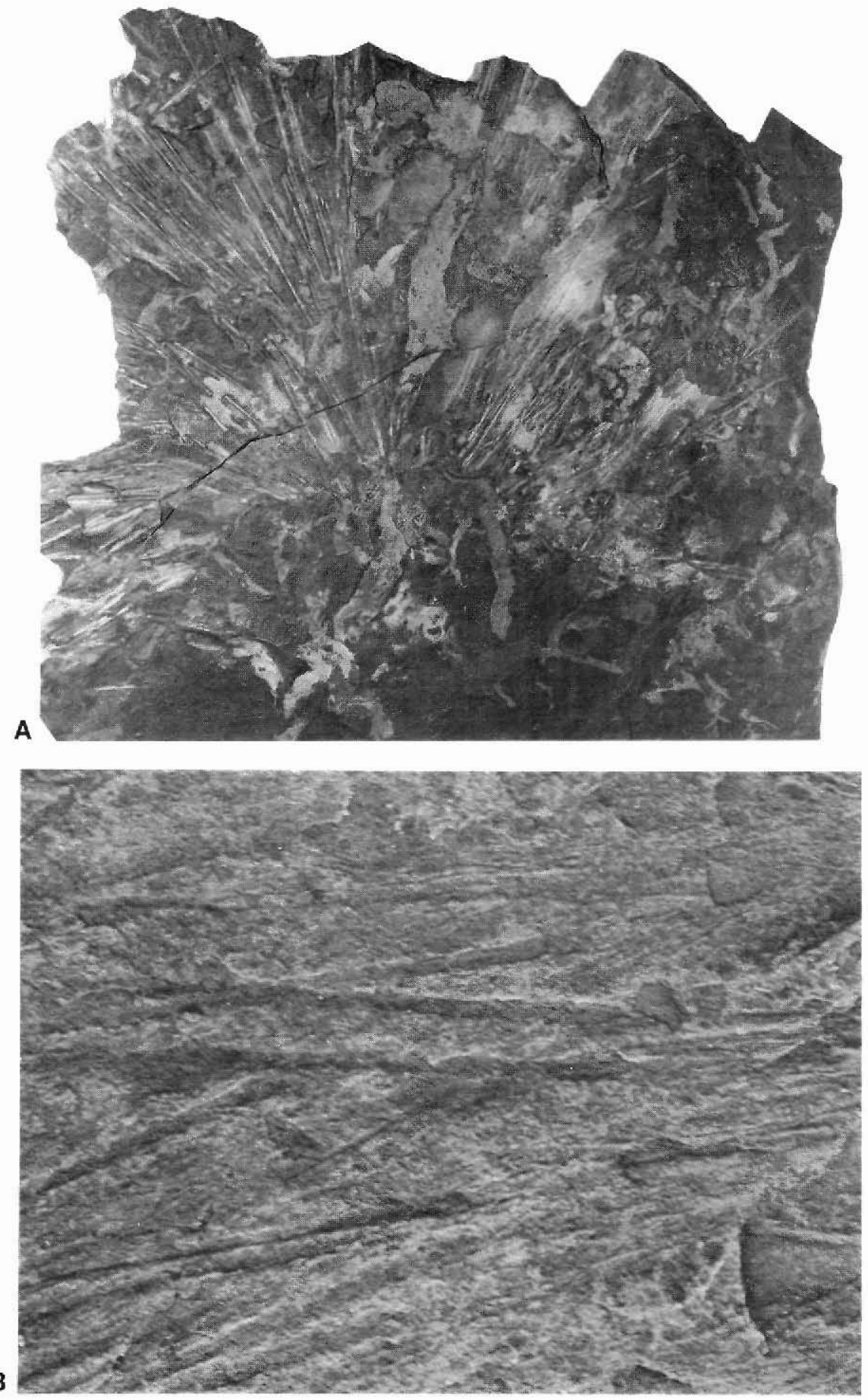
Spicules of the fine part of the thatch are generally of two sizes (fig. 4B). The coarser ones are approximately $0.05-0.06 \mathrm{~mm}$ in maximum diameter and range up to 8-10 $\mathrm{mm}$ long in the few spicules where both tips are moderately well-preserved. These coarse spicules are generally spaced $0.1-0.3 \mathrm{~mm}$ apart in the thatch and are separated by somewhat finer spicules that are tightly packed, side-by-side. The finer spicules are approximately $0.02-0.03 \mathrm{~mm}$ in diameter and appear to be shorter, although rarely are both tips of individual spicules evident in the dense packing. Where most complete, they appear to be $5.0-6.0 \mathrm{~mm}$ long, but with considerable variation. Because of difficulty in tracing the spicules, many of what appear to be tiny spicules in reality may be tips of coarser elements of the thatch.

Two skeletal layers are recognisable in MGUH 17071: a lower layer in which coronal spicules make up approximately one-third the volume of the thatch, and an upper layer where coarse spicules are largely wanting. Original thicknesses of these two layers within the sponge are uncertain because of flattening of the specimen. The upper layer, where the spicules are tightly packed, appears to have been only 2 or $3 \mathrm{~mm}$ thick, based upon how the fine thatch appears to imbricate in places where three-dimensional relationships are most evident. Such a relationship is present in the upper centre, as shown in fig. 3.

Discussion. Choia hindei (Dawson, 1896) is the largest species of the genus known, both in terms of gross morphology of the central disc and in size of the coronal spicules. Choia hindei is at least 10 times larger than small Choia ridleyi Walcott, 1920 as described by Walcott (1920, p. 294) and Rigby (1986, p. 28) and is 3-5 times larger than Choia utahensis Walcott, 1920 as described by Walcott $(1920$, p. 295), Robison (1964, p. 564) and Rigby (1978, pp. 1331-1332; 1983, pp. 252-253; 1986, text-fig. 14). Dawson (1896, p. 117) initially described the species Choia hindei from black argillaceous rocks near Metis on the south shore of the St. Lawrence estuary on the Gaspé Peninsula in south-eastern Quebec. Dawson originally thought the beds were Cambrian but Howell (1944) concluded that the black shales exposed along the St. Lawrence shore are of Early Ordovician and not Cambrian age. The first known Cambrian specimens of Choia hindei were described by Rigby (1983, pp. 253-255) from the Marjum Formation of western Utah. The specimens from Greenland are similar in spicule dimensions but are larger in disc dimensions.

Gorjanskay (1977) described a single specimen of Lower Cambrian sponge from the Lena River area of eastern Siberia and named the new genus and species Lenica unica. His specimen is essentially identical to the Greenland Choia hindei in dimensions of both central thatch and coronal spicules and in indicated size of the sponge. The Siberian sponge is also like the type described by Dawson (1986, p. 117) and Walcott (1920, pp. 295-296). Lenica unica is considered as a synonym for Choia hindei.

Fig. 4. A, Choia hindei (Dawson, 1896) showing characteristic radiate thatch of the central disc in the lower centre, surrounded by light limonite-replaced coronal spicules, that together make up approximately three-quarters of a complete sponge. The central disc is somewhat obscured by matrix and fragments of ?Vauxia, but the light coronal spicules show well as both replacements and bas-relief impressions. This is one of the largest known specimens of the species. Early Cambrian, North Greenland, from the Buen Formation MGUH 17070 from GGU sample 319543, $\times 0.5$. B, photomicrograph of Choia hindei showing marked contrast between the small thatch of spicules of the central disc and the coarse coronal oxeas. The small spicules show best in the upper right as bas-relief impressions that obscure tips of the coarse coronal oxeas. MGUH 17071 from GGU sample 313035, × 10. 
Perhaps the most similar coarse-textured Cambrian sponge with which Choia hindei might be confused is Halichondrites elissa Walcott, 1920 as described by Walcott (1920, pp. 270271) and Rigby (1986, pp. 31-32, Pl. 10, figs 1, 2; text- fig. 16). Halichondrites has spicules of essentially the same length as those evident as coarse coronal spicules in Choia hindei, but lacks the prominent bimodel distribution of coarse and fine spicules in the skeleton. Rather, it appears to be made of spicules with a range of sizes. In addition, Halichondrites is a steeply obconical, funnel-shaped sponge. Were it inverted or were Choia flattened sideways, the two might be confused, except for the strong contrast in spicule makeup of the skeleton, with Choia having a skeleton made of two distinct sizes of spicules and Halichondrites of a more or less continuous gradational series.

Material. MGUH 17071 from GGU sample 313035, and MGUH 17070 from GGU sample 319543, Buen Formation (Early Cambrian), North Greenland. In addition, ten other somewhat fragmentary specimens were collected from locality 2 (GGU sample 319543) and two specimens from locality 3 (GGU sample 319711).

\author{
Class Hexactinellida Schmidt, 1870 \\ Order Lyssacinosa Zittel, 1877 \\ Superfamily Protospongioidea Hinde, 1887 \\ Family Protospongiidae Hinde, 1887 \\ Genus Diagoniella Rauff, 1894
}

Type species. Protospongia coronata Dawson, 1889.

\title{
Diagoniella mica sp. nov.
}

Figs $2 \mathrm{~A}, 5$

Diagnosis. Tiny subglobular, thin-walled sponge with a simple large spongocoel; lacking nodes or other surface ornamentation; unbranched, lacks marginalia and prostalia but may have a short obconical root tuft. Skeletal net of ranked, diagonally-oriented, stauractines of at least three orders.

Description. This single small specimen is a flattened globular impression, approximately 6 $\mathrm{mm}$ high and with a maximum width of $4.5 \mathrm{~mm}, 2 \mathrm{~mm}$ below the oscular margin. It has a rounded base, $2.5-3.0 \mathrm{~mm}$ across, below which extends an obscure impression of what are interpreted to be convergent root tuft spicules. The surface is smooth with rounded upper and lower parts so the sponge appears like a miniature hot air balloon (figs $2 \mathrm{~A}, 5$ ). It has a skeletal net of ranked stauractines, particularly well-exposed in the lower part of the sponge but essentially present as ghost-like impression in the upper part. No hexactines are evident and the entire skeleton appears to be made of stauracts in which the rays do not meet at $90^{\circ}$. Characteristically, in the middle part of the sponge, acute angles between rays are vertical from ray junctions and obtuse angles, which range up to approximately $120^{\circ}$, are horizontally arranged from the ray junction.

First-order stauracts have rays approximately $0.8 \mathrm{~mm}$ long and with a basal ray diameter of $0.03-0.04 \mathrm{~mm}$. These and all spicules in the skeleton appear smooth and have rays that 
Fig. 5. Camera lucida drawing of the holotype of Diagoniella mica sp. nov., which appears to have been flattened diagonally. Details of both rounded ends are largely obscured. The near basal rectangles are less prominently diagonally-oriented than are those of the ranked stauractines in upper part of the skeleton. Details of the skeleton show best at about midlength. Late Silurian, Chester Bjerg Formation, MGUH 17076 from GGU sample $315484, \times 10$.

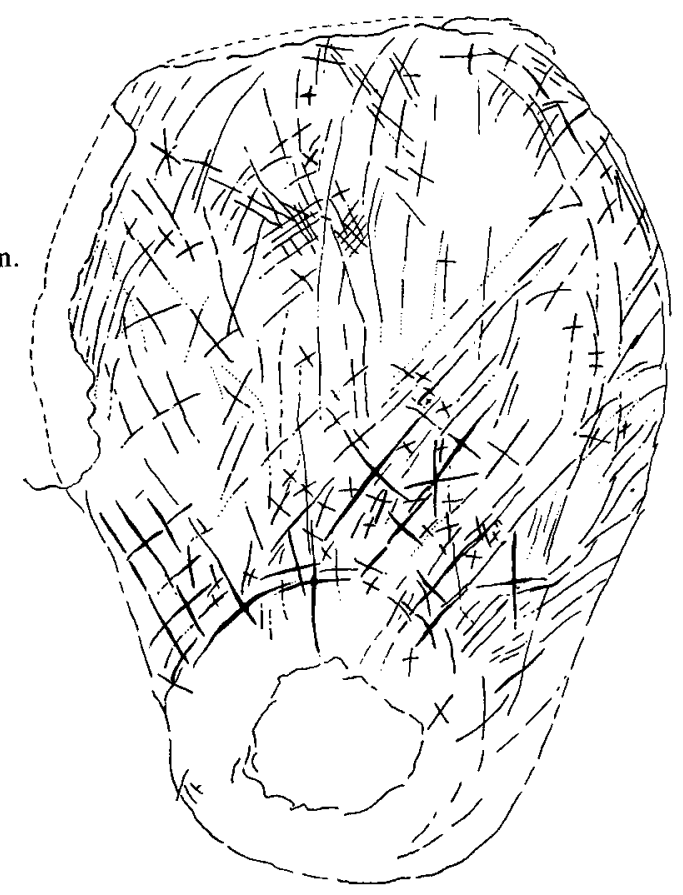

taper uniformly from the basal junction to moderately sharp tips, as best defined in the pyritic replacement. First-order spicules outline somewhat diamond-shaped quadrules that are approximately $0.5 \mathrm{~mm}$ across, from side to side.

First-order quadrules are subdivided by second-order stauracts that have rays approximately $0.4 \mathrm{~mm}$ long, with basal ray diameters of approximately $0.03 \mathrm{~mm}$. Second-order quadrules are approximately $0.25 \mathrm{~mm}$ across. Third-order spicules have rays approximately $0.20-0.25 \mathrm{~mm}$ long and basal ray diameters, at their common junction, of $0.020-0.025 \mathrm{~mm}$. They subdivide the second-order quadrules into smaller divisions, approximately $0.18-0.25$ $\mathrm{mm}$ wide from side to side, but only a few such quadrules are preserved in the skeleton.

A few fourth-order spicules, with rays $0.14-0.16 \mathrm{~mm}$ long and with basal ray diameters of $0.010-0.015 \mathrm{~mm}$, occur as somewhat irregularly oriented, isolated stauracts in part of the net. Only in the lower right part of the sponge, as figured, are these spicules somewhat parallel to higher ranks and produce small quadrules. Even smaller spicules occur as isolated rare elements. They have rays approximately $0.10 \mathrm{~mm}$ long and basal ray diameters of $0.008-0.010 \mathrm{~mm}$. These are the smallest elements that are preserved in the pyritic replacement.

The oscular rim of the specimen is not preserved on the available counterpart. The sponge is flattened somewhat diagonally so that the basal area shows moderately well, but the oscular rim is buried in matrix beneath the upper part of the impression.

Convergence of some straight rays and ghost-like colour patterns in the lower part of the sponge suggest a root tuft that is approximately $1 \mathrm{~mm}$ across at the top. The triangular impression extends to approximately $5 \mathrm{~mm}$ below the rounded base of the sponge. Structure of the possible tuft, however, is obscured in the combination of moderately massive pyrite and 
grey matrix where only colour bands show in the dolomitic siltstone matrix. In this same general area, a moderately uniformly spaced series of subvertical radiating lines in the matrix appear almost as stauracts, with rays parallel to principal axes of the sponge, as though the basal first-order quadrule may have had a protosponge orientation. The skeletal pattern abruptly shifts, however, to a diagonal pattern that persists through the rest of the skeleton.

Discussion. Diagoniella tubulara Rigby \& Harris, 1979 is the only other species of Diagoniella described from Silurian rocks (Rigby \& Harris, 1979, pp. 970-974). It occurs in Early Silurian (Llandovery) age rocks from northern British Columbia, near the small community of Ware. Diagoniella tubulara is a considerably coarser sponge, however, and also is branched. It has subcylindrical to high obconical branches up to $112 \mathrm{~mm}$ long and, thus, differs sharply from $D$. mica sp. nov., described here.

This Late Silurian (Ludlow) species from Greenland appears more similar to Diagoniella coronata (Dawson, 1889) as described by Dawson (1889, pp. 429-430) and by Dawson in Dawson \& Hinde (1890, p. 41, text-figs 8-10, pl. 3, fig. 4). Diagoniella coronata is a small globular sponge with a skeletal net of ranked stauractines, essentially like that of the Silurian Greenland species, and also has a somewhat modified root tuft at the rounded base. However, it has marked long prostalia around the oscular rim, as well as distinct marginalia, as interpreted by Dawson. In addition, it is somewhat larger than $D$. mica sp. nov. from North Greenland.

Diagoniella cyathiformus (Dawson, 1889) as described by Dawson $(1889$, p. 43, figs 13 , 14 ) is a distinctly conical form and is considerably larger than the tiny species from Greenland. $D$. cyathiformus also has marked prostalia and a well-defined root tuft on the rounded base. $D$. mica is considerably smaller than Cambrian representatives of Diagoniella cyathiformus (Dawson, 1889) described by Rigby (1978, pp. 1336-1337; 1983, pp. 255-257) from the Wheeler and Marjum and equivalent formations of Utah and Nevada. Diagoniella hindei Walcott, 1920 as described by Walcott $(1920$, pp. 310-311) is a small Cambrian form but tends to be more distinctly obconical or conical-cylindrical than the globular Silurian Diagoniella mica.

This sponge extends the globular form of Diagoniella from the Cambrian into the late Silurian. The sponge occurs with numerous fragments of Monograptus that also have been partially pyritized and occur scattered over bedding planes.

Material. MGUH 17076 from GGU sample 315484, the holotype and only known specimen; Chester Bjerg Formation (Late Silurian), Nyeboe Land, North Greenland.

Acknowledgments. MGUH and GGU denote the collections of the Geological Museum and Geological Survey of Greenland, respectively; all illustrated specimens are deposited in the former institution. Appreciation is extended to J. S. Peel who arranged loan of the specimens for study. Together with A. K. Higgins and P.-H. Larsen, he also provided stratigraphic and geographic information on the occurrences. Examination and description of the fossils formed part of a study of Early Palaeozoic sponges, partially supported by National Science Foundation project DEB 8200860. This funding, together with the support of the Department of Geology, Brigham Young University, Provo, is greatly appreciated. 


\section{References}

Bengtson, S. \& Missarzhevsky, V. V. 1981: Coeloscleritophora - a major group of enigmatic Cambrian metazoans. In Taylor, M. E. (edit.) Short papers for the Second International Symposium on the Cambrian System. U. S. Geol. Survey Open-file Report 81-743, 19-21.

Dawson, J. W. 1889: On fossil sponges from beds of the Quebec Group of Sir William Logan, at Little Métis (abstract). Canad. Rec. Sci. 3, 7, 429-430.

Dawson, J. W. 1896: Additional notes on fossil sponges and other organic remains from the Quebec Group of Little Métis on the lower St. Lawrence; with notes on some of the specimens by Dr. G. J. Hinde. Trans. Roy. Soc. Canada 2, 2, 4, 91-121.

Dawson, J. W., \& Hinde, G. J. 1890: New species of fossil sponges from the Siluro-Cambrian at Little Métis on the Lower St. Lawrence. Trans. Roy. Soc. Canada 7, 4, 31-55.

Gorjansky, V. Yu. 1977: First find of remains of a sponge in the Lower Cambrian of East Siberia. Ezhegodnik Vses. Paleont. Obshch. 20, 274-276 [in Russian].

Howell, B. F. 1944: The age of the sponge bed at Little Metis, Quebec. Bull. Wagner Free Inst. Sci. 19, $1,16 \mathrm{pp}$.

Larsen, P.-H. \& Escher, J. C. 1985: The Silurian turbidite sequence of the Peary Land Group between Newman Bugt and Victoria Fjord, western North Greenland. Rapp. Grønlands geol. Unders. 126, 4767.

Peel, J. S. 1982: The Lower Paleozoic of Greenland. In Embry, A. F. \& Balkwill, H. R. (edit.) Arctic geology and geophysics. Mem. Can. Soc. Petrol. Geol. 8, 309-330.

Poulsen, C. 1937: On the Lower Ordovician faunas of East Greenland. Meddr Grønland 119, 3, 72 pp.

Rigby, J. K. 1978: Porifera of the Middle Cambrian Wheeler Shale, from the Wheeler Amphitheater, House Range, in western Utah. J. Paleont. 52, 1325-1345.

Rigby, J. K. 1980: The Middle Cambrian sponge Vauxia magna from the Spence Shale of northern Utah and taxonomic position of the Vauxiidae. J. Paleont. 54, 234-240.

Rigby, J. K. 1983: Sponges of the Middle Cambrian Marjum Limestone from the House Range and Drum Mountains of western Millard County, Utah. J. Paleont. 57, 240-270.

Rigby, J. K. 1986: Sponges of the Burgess Shale (Middle Cambrian), British Columbia. Palaeontographica Canadiana 2, 105 pp.

Rigby, J. K., \& Harris, D. R. 1979: A new Silurian sponge fauna from northern British Columbia, Canada. J. Paleont. 53, 968-980.

Robinson, R. A. 1964: Late Middle Cambrian faunas from western Utah. J. Paleont. 38, 510-566.

Troedsson, G. 1928: On the Middle and Upper Ordovician faunas of Northern Greenland. Part II. Meddr Grønland 47, 1, 197 pp.

Walcott, C. D. 1920: Cambrian geology and paleontology IV, Middle Cambrian Spongiae. Smithsonian Misc. Coll. 67, 261-364. 